\title{
INNOVATIVE BREAKWATERS DESIGN FOR WAVE ENERGY CONVERSION
}

\author{
D. Vicinanza ${ }^{1,2}$, D. Stagonas ${ }^{3}$, G. Müller ${ }^{3}$ J. H. Nørgaard ${ }^{1}$ and T. L. Andersen ${ }^{1}$
}

This paper intends contributing to an economically and environmentally sustainable development of coastal infrastructures by investigating the possibility of combining together breakwaters and Wave Energy Converters (WEC). The latter change the wave energy to electricity, which may serve both the rubble mound breakwaters and seawalls related activity and the energy demand of small human communities. Wave loadings and overtopping on a seawall and rubble mound breakwater with front reservoir are discussed on the basis of physical 2-D model tests carried out at University of Southampton (UK) and Aalborg University (DK).

Keywords: wave energy converters; seawalls; rubble mound breakwaters; front reservoir

\section{INTRODUCTION}

Following the continuous economic crisis of the developed world an increasing emphases is given on stimulating growth through 'green' development. By definition the latter involves, among others, investments on innovative renewable energy schemes. Ocean energy generation has a potential to reach $3.6 \mathrm{GW}$ of installed capacity by 2020 and close to $188 \mathrm{GW}$ by 2050 . This represents over $9 \mathrm{TWh} /$ year by 2020 and over $645 \mathrm{TWh} /$ year by 2050, amounting to $0.3 \%$ and $15 \%$ of the projected EU-27 electricity demand by 2020 and 2050 respectively (EOEA, 2012).

Today, the largest problem in harvesting wave energy is ensuring the reliability of the technology and bringing the costs down. Along these lines, the design goals for coastal engineers have started to shift from defending against wave energy towards harvesting wave energy and in some cases both.

Although well required, ports, coastal defenses and sea dikes represent vast investments with large return periods; arguably the concept of investment return period could not even apply for defense structures such as seawalls and rubble mound breakwaters. In the same time, climate change evidence, like e.g. increased storminess and sea level rise, and the demand for positive growth rates challenge the effectiveness and sustainability of all existing coastal infrastructure. Seawalls and breakwaters need to be higher and stronger, and increased periods of calm conditions within ports are necessary for the reduction of down times.

The requirement for more efficient and sustainable coastal structures can be potentially fulfilled through the development of hybrid Wave Energy Converters (WEC), which are based on the wave action to produce electricity and in the same time enhance the performance of traditional breakwaters.

Composite sea walls, i.e. sea walls on a high rubble mound which have an energy absorbing screen or a slit wall in front of the impermeable wall, have been recently constructed in Mori port, Japan (Mori et al., 2008). Such structures have been reported to reduce construction costs of seawalls by up to $30 \%$ and lower the environmental impact of construction. In the same time, field measurements indicated reduced wave loadings on the seawall; the energy of breaking waves is dissipated by the screen, and by the turbulence created by the impact of the breaker's jet onto the water between screen and wall.

A similar concept has also been proposed by Geeraerts et al. (2006) for the reduction of wave overtopping on sea dikes. A basin is placed in between two walls and the incoming wave impacts on the seaward wall, directs upwards and drops in the basin were most of its energy is dissipated.

Burcharth and Lykke Andersen (2006) presents the results of a comprehensive 2-D model test study performed by the Hydraulics and Coastal Engineering Laboratory at Aalborg University, Denmark for ESTUDIO 7, Las Palmas and the Public Authorities of Gran Canaria, with the objective of optimizing the design of a new breakwater for the extension of Agaete Port. In cases where low crests and small overtopping discharges are demanded, the Authors demonstrated that front reservoir solutions are very efficient and more economical than conventional cross section solutions, such as bermed structures and mild slope structures (Fig. 1). The stability of the armour in the reservoir and the wave forces on an inner wall were found very sensitive to the width of the reservoir.

\footnotetext{
${ }^{1}$ Department of Civil Engineering, Aalborg University, Sohngaardsholmsvej 57, Aalborg, DK-9000 Denmark, dv@civil.aau.dk, ihn@civil.aau.dk, tla@civil.aau.dk

${ }^{2}$ Department of Civil Engineering, Second University of Naples, via Roma 29, 81031, Aversa (CE), Italy, diego.vicinanza@unina2.it

${ }^{3}$ Sustainable Energy Research Group, School of Civil Engineering and the Environment, University of Southampton, Highfield, SO17 1BJ, Southampton, United Kingdom, ds204@soton.ac.uk, g.muller@soton.ac.uk
} 


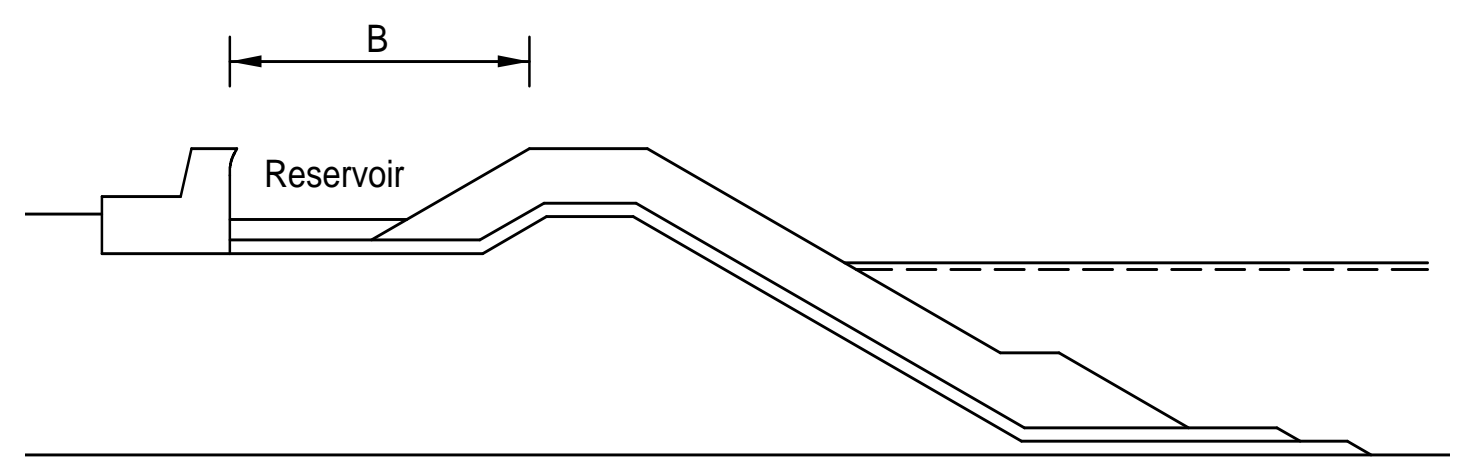

Figure 1. Rubble mound with a front reservoir after Burcharth \& Lykke Andersen (2006).

Stagonas et al. (2010) proposed a composite seawall designed as a reservoir placed in front of a seawall (Figure 2). The incoming wave impacts on the sloping seaward wall of the reservoir, directs upwards and drops in the reservoir were most of its energy is dissipated. Although, the head difference generated will be small (in the range of the wave height), the structure allows for a long capture length, which can be almost equal to the breakwater's length. As a result the structure fulfils a double purpose, and its cost-effectiveness increases, as it provides protection and in the same time generates energy.

In opposition to most existed (period dependant) wave energy converters, the performance of the seawall appears to depend mainly on the incoming wave height rather than the wave period. Obviously, the optimum crest height (Rc) must be determined as a function of the local wave climate.

In order to generate the potential for a robust and cost-effective wave energy converter for very low head differences, such seawall may be combined with a specifically designed hydropower converter. A new type of low head energy converters was recently developed in the University of Southampton, UK. HPW consists of a wheel of radius R, whose blades also act as a weir, creating a head difference. The hydrostatic force difference (between up and downstream) acts on the blades, which move with the velocity of the upstream water flow. Consequently the hydrostatic force moves with the same velocity.

Despite its simple appearance, the HPW seems to constitute a novel type of hydraulic energy converter with high efficiencies, and with the intriguing property that its efficiency increases with reducing head difference. This is due to the fact that the velocity of the water close to the wheel must reduce due to the increase in water depth. The theoretical and experimental efficiency of the HPW ranging between $65 \%$ and $95 \%$.

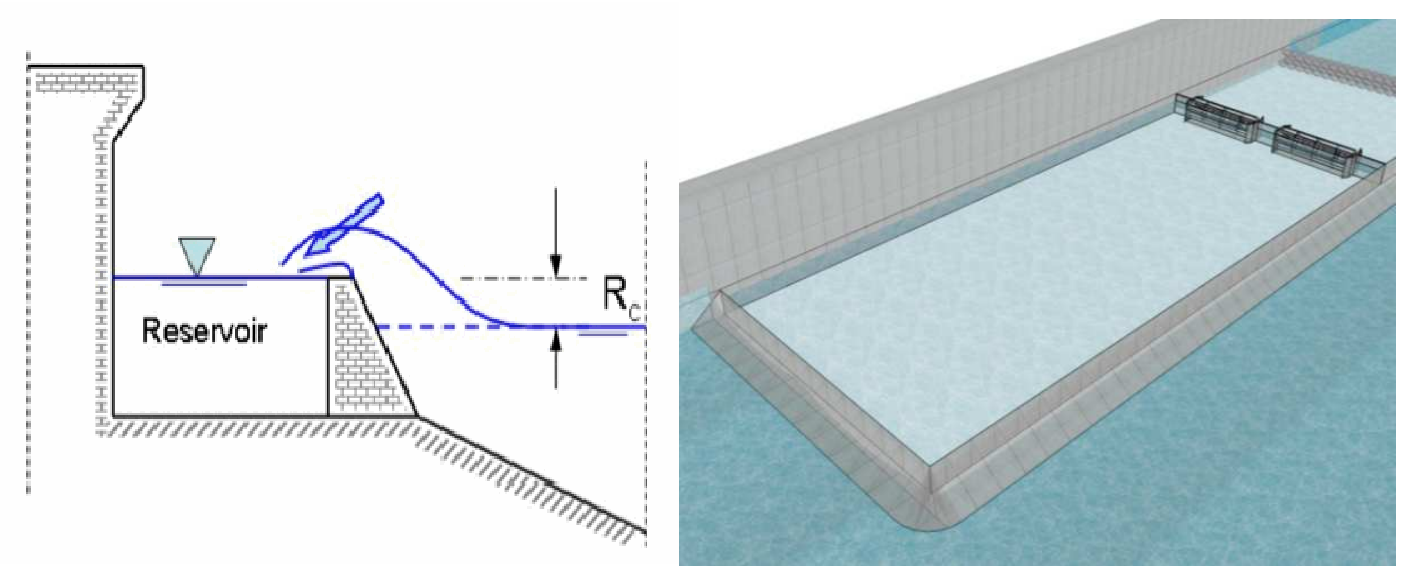

Figure 2. Schematic representation of the energy capturing composite seawall (after Stagonas et al., 2010). 
Vicinanza et al. (2012) reviewed the most significant findings on the Sea-wave Slot-cone Generator (SSG). This Wave Energy Converter is based on the wave overtopping principle; it employs several reservoirs placed on top of each other, in which the energy of incoming waves is stored as potential energy (Fig. 3). Then, the captured water runs through turbines for electricity production. The system works under a wide spectrum of different wave conditions, giving a high overall efficiency. It can be suitable for shoreline and breakwater applications and presents particular advantages, such as sharing structure costs, availability of grid connection and recirculation of water inside the harbour, as the outlet of the turbines is on the rear part of the system (Fig. 3). The system has undergone six years of R\&D, at the Department of Civil Engineering of Aalborg University (Denmark). The research has focused mainly on the maximization of wave power capturing ("hydraulic response", see Margheritini et al., 2009) and on the nature and magnitude of wave loadings ("structural response", see Vicinanza and Frigaard, 2008 and Vicinanza et al., 2011).

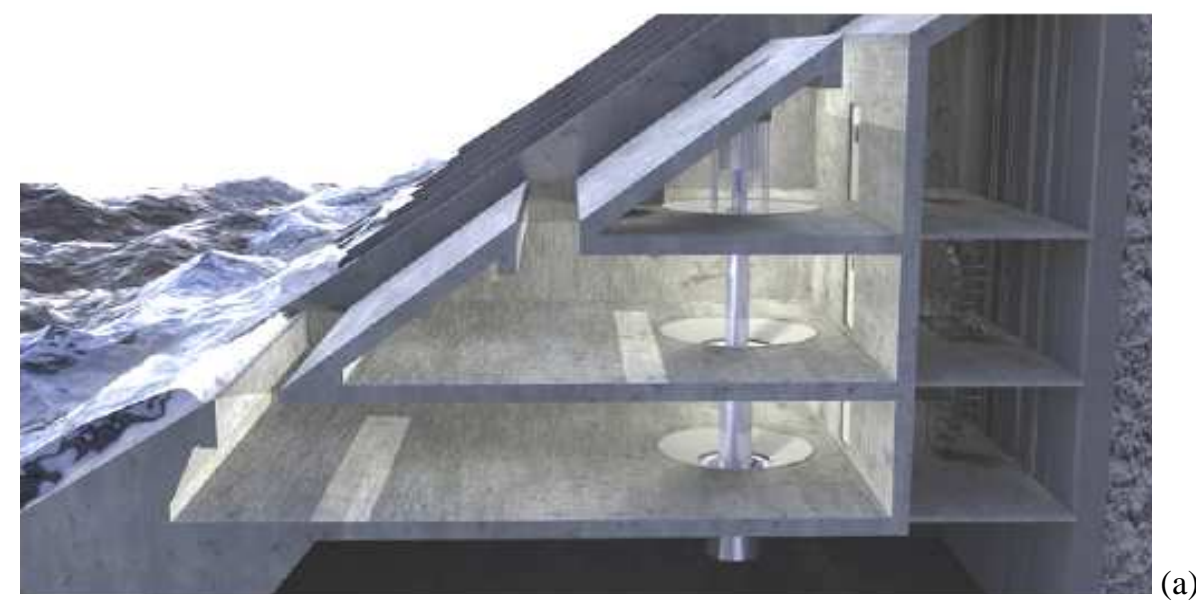

(a)

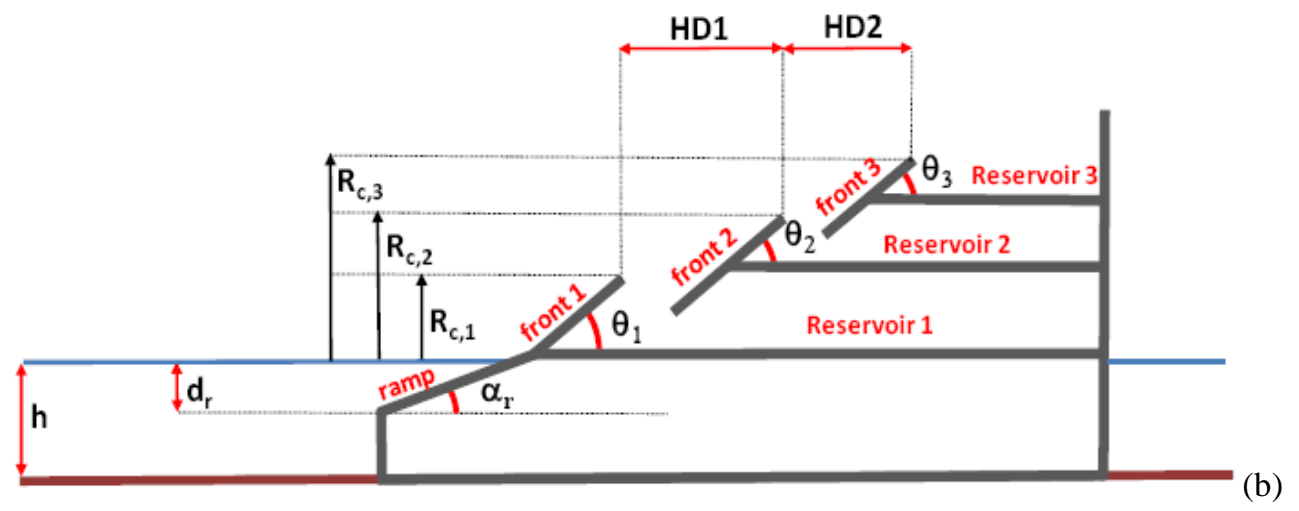

Figure 3. a) Artistic representation of a 3-level SSG with multistage turbine.; b) Definition sketch for a 3-level structure (after Vicinanza et al., 2012).

Moving from the previous experience of the Authors an innovative design will be introduced. The main aim is to show performances of a seawall named Sea Wall wave OverTopping Device (SW-OTD) and a rubble mound breakwaters with a front reservoir designed with the aim of using the wave overtopping to produce electricity named Overtopping BReakwater for Energy Conversion (OBREC). The primary function of the device will remain the harbor/coastal protection but with the principal aim of costs reduction. The new design should be capable of adding a revenue generation function to a breakwater while adding cost sharing benefits due to integration. The design can be applied to harbor expansions, existing breakwater reparation or upgrade due to climate change for a relatively low price considering the breakwater would be built regardless of the inclusion of a WEC. 


\section{SEA WALL WAVE OVERTOPPING DEVICE}

Experiments were conducted at University of Southampton (UK) on a Sea Wall wave OverTopping Device (SW-OTD) in two wave tanks, $7 \times 0.2 \times 0.2 \mathrm{~m}$ and $12 \times 0.5 \times 0.45 \mathrm{~m}$, assuming a model scale of 1:50 and 1:23 respectively (Figure 4).

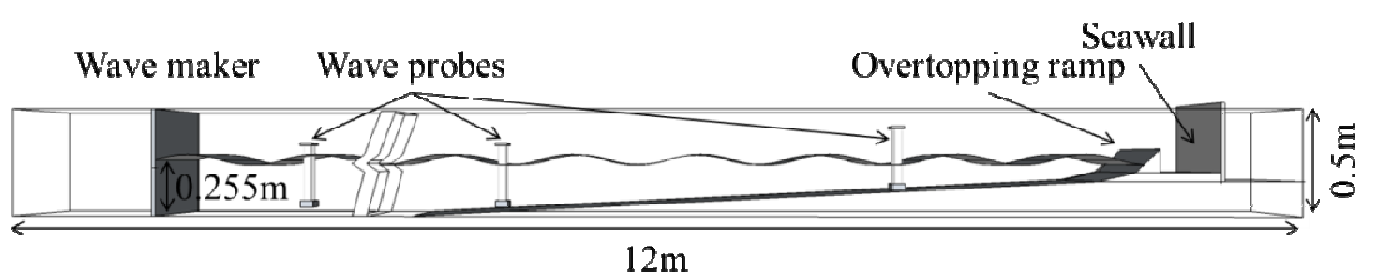

(a)
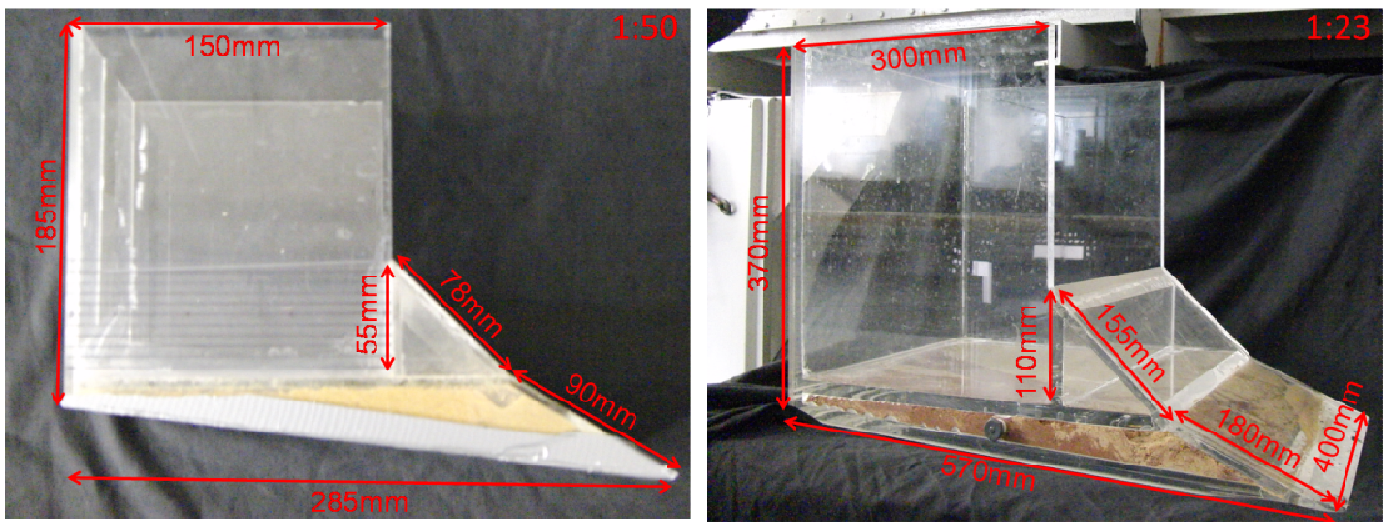

(b)

Figure 4. a) Experimental arrangement used for the 1:23 scale experiments; b) 1:50 and 1:23 models.

The main experimental objectives were to establish the hydraulic power capacity and efficiency of the structure and investigate the double role of structure during extreme conditions; overtopping and wave pressures were measured for a vertical wall and the composite sea wall.

Overtopping was measured for two different freeboard heights and two seabed slope for the small and the larger scale model respectively (Tab. 1). The sloping front wall was positioned with a slope of $\theta=45^{\circ}$. Regular waves were testes as a preliminary study of the performance regarding overtopping and loadings.

\begin{tabular}{|c|c|c|c|c|c|c|c|c|c|c|}
\hline $\begin{array}{l}\text { Test } \\
\text { scale }\end{array}$ & $\begin{array}{l}\text { bed } \\
\text { Slope }\end{array}$ & $\begin{array}{c}\mathrm{h} \\
{[\mathrm{m}]}\end{array}$ & $\begin{array}{c}\mathrm{H} \\
{[\mathrm{m}]}\end{array}$ & $\begin{array}{c}\mathrm{T} \\
{[\mathrm{s}]}\end{array}$ & $\begin{array}{c}\mathrm{R}_{\mathrm{C}} \\
{[\mathrm{m}]}\end{array}$ & $\begin{array}{c}B \\
{[\mathrm{~m}]}\end{array}$ & $\begin{array}{c}\mathrm{H} / \mathrm{L} \\
{[-]}\end{array}$ & $\begin{array}{l}\mathrm{H} / \mathrm{h} \\
{[-]}\end{array}$ & $\begin{array}{c}\mathrm{R}_{\mathrm{C}} / \mathrm{H} \\
{[-]}\end{array}$ & $\begin{array}{c}\mathrm{B} / \mathrm{L} \\
{[-]}\end{array}$ \\
\hline $1: 50$ & $1: 10$ & 0.12 & $\begin{array}{l}0.020 \\
0.050\end{array}$ & $\begin{array}{l}0.5 \\
1.4\end{array}$ & $\begin{array}{l}0.02 \\
0.03\end{array}$ & 0.150 & $\begin{array}{l}0.051 \\
0.016\end{array}$ & $\begin{array}{l}0.17 \\
0.42\end{array}$ & $\begin{array}{c}1 \\
0.6\end{array}$ & $\begin{array}{l}0.38 \\
0.05\end{array}$ \\
\hline $1: 23$ & $1: 20$ & 0.25 & $\begin{array}{l}0.03 \\
0.09\end{array}$ & $\begin{array}{l}0.74 \\
2.06\end{array}$ & $\begin{array}{l}0.044 \\
0.065\end{array}$ & 0.300 & $\begin{array}{l}0.035 \\
0.014\end{array}$ & $\begin{array}{l}0.12 \\
0.36\end{array}$ & $\begin{array}{l}1.47 \\
0.72\end{array}$ & $\begin{array}{l}0.35 \\
0.05\end{array}$ \\
\hline
\end{tabular}

For each experiment a wave train of six waves was generated and the volume of water collected in the reservoir was measured for three consecutive waves. After each experimental run the water collected in the reservoir was removed and weighted, leaving the chamber empty for the next test. Accordingly, overtopping volumes and wave heights measured by three resistance type wave probes were used for the calculation of the ramps efficiency and power potential.

Overtopping and pressure measurements were conducted separately. Pressure records were acquired by an array of 6 pressure transducers sampling at $2000 \mathrm{~Hz}$ and placed at $3 \mathrm{~cm}$ intervals in the middle of the seawall. 
The preliminary analysis is concerning the overtopping performances and pressure distribution on traditional seawall and the innovative seawall with a front reservoir.

\section{Overtopping}

The non-dimensional average overtopping discharge in the reservoir $\left(Q^{*}\right)$ and reservoir crest freeboard $\left(\mathrm{R}_{\mathrm{c}}^{*}\right)$ are defined as:

$$
\begin{gathered}
Q^{*}=\frac{q}{\sqrt{g \cdot H^{3}}} \\
R_{c}^{*}=\frac{R_{c}}{H}
\end{gathered}
$$

where $\mathrm{q}$ is the average overtopping rate $\left(\mathrm{m}^{3} / \mathrm{s}\right.$ per $\mathrm{m}$ width) and $\mathrm{R}_{\mathrm{c}}$ is the crest freeboard $(\mathrm{m})$.

Measured overtopping for 1:50 model and 1:23 model are plotted in Figure 5 and in Figure 6.

The measured overtopping in the reservoir will be used to calculate later the hydraulic power and hydraulic efficiency of the structure.

The comparison between average overtopping rate on the rear side of the traditional seawall and the seawall with front reservoir show a reduction of the amount of water that overtops the seawall by up to $60 \%$ (Stagonas et al., 2010).

\section{Pressure distribution}

Preliminary results of measured wave induced pressures on the vertical wall of SW-OTD were found to even more than 7 times smaller than pressures on the vertical wall (Fig. 7). The pressures on the reservoir sloping front wall were not measured at this first experiment. Video recorded show a significant amount of wave energy dissipation induced by the sloping reservoir wall. The direct collision of the wave with the vertical wall does not take place any more, only the jet of the wall hits the bottom slab.

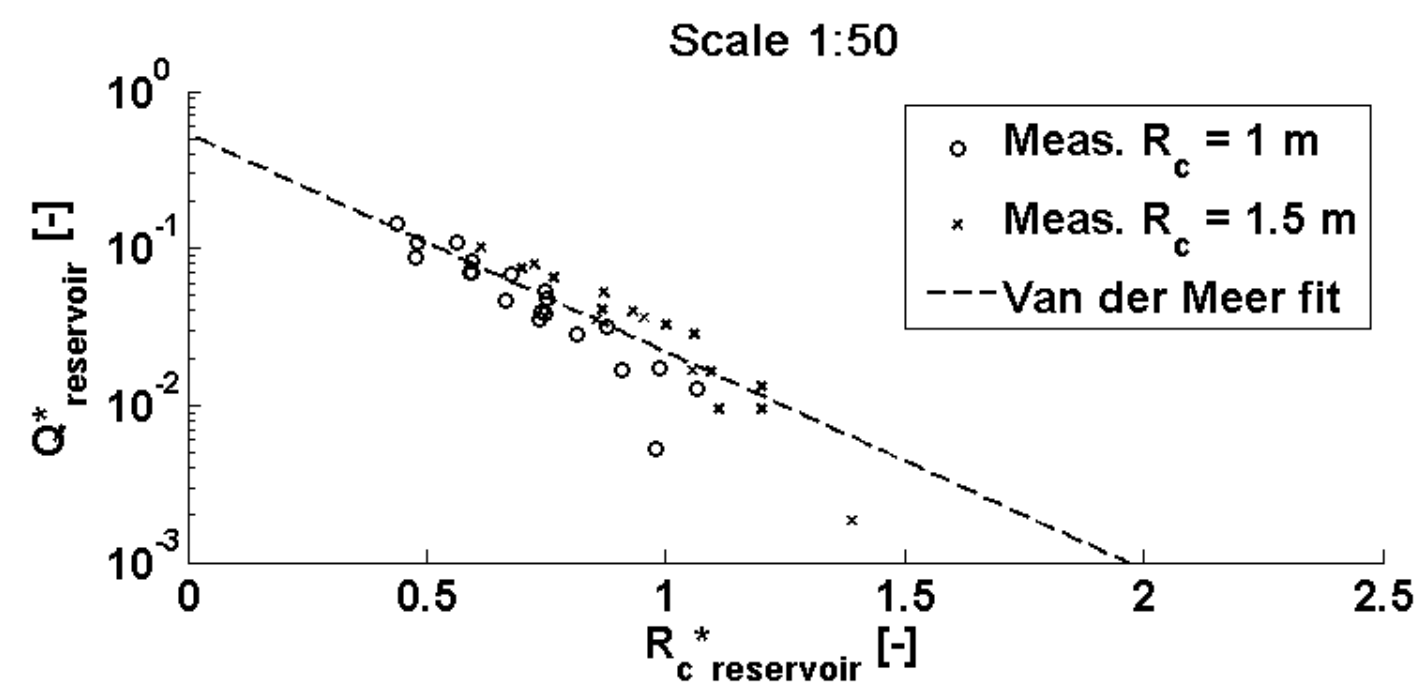

Figure 5. Van der Meer (1008) vs measured front reservoir overtopping discharge (model scale 1:50). 


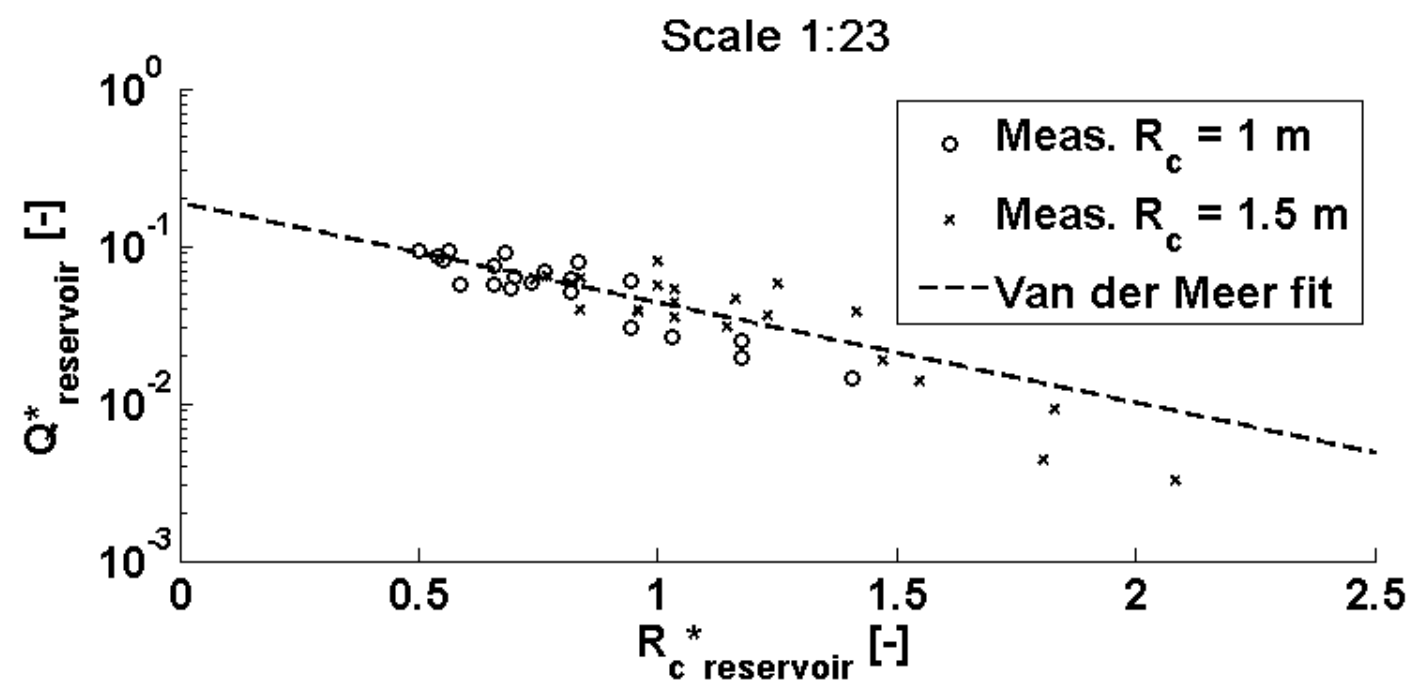

Figure 6. Van der Meer (1008) vs measured front reservoir overtopping discharge (model scale 1:23).

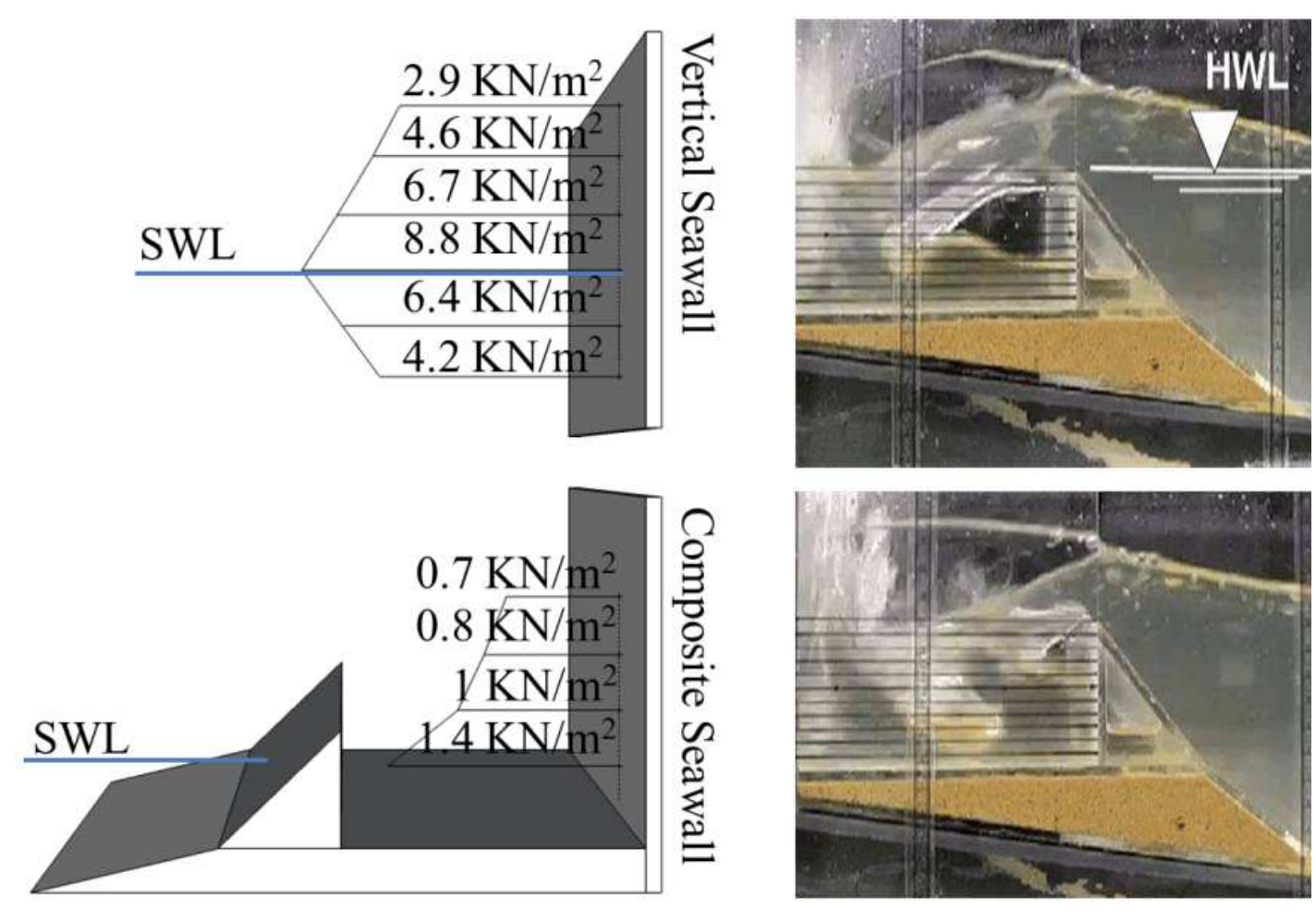

Figure 7. a) Measured pressure distribution on traditional seawall and SW-OTD; b) Image sequence of the initial jet impact and the subsequent up-rush and turbulence.

\section{OVERTOPPING BREAKWATER FOR ENERGY CONVERSION}

2D hydraulic model tests were carried out at the Department of Civil Engineering, Aalborg University (DK) assuming a model scale of 1:30. Two models were installed (Fig. 8 and 9): a traditional rubble mound breakwater with a crown wall (Nørgaard et al., 2012 in this proceedings) and the innovative Overtopping BReakwater for Energy Conversion (OBREC). 


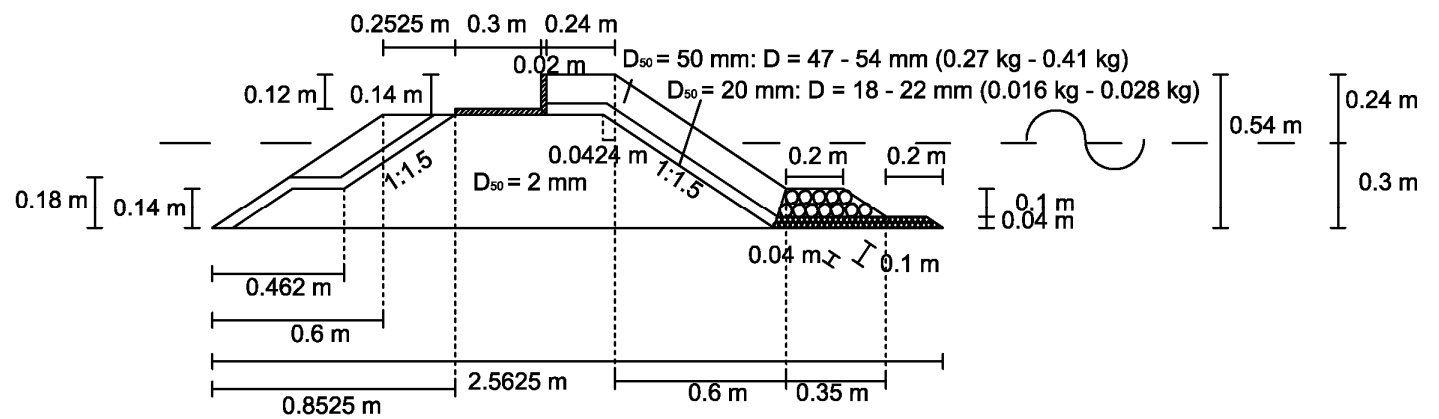

Figure 8. Cross-section of models tested at Aalborg University (traditional rubble mound breakwater).

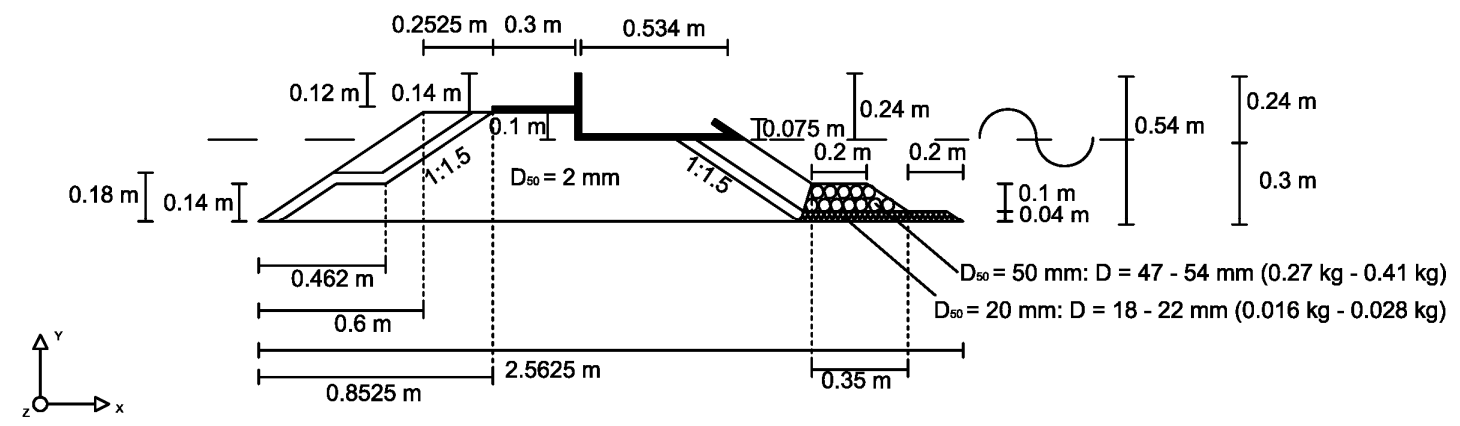

Figure 9. Cross-section of models tested at Aalborg University (innovative breakwater).

The wave flume is $1.5 \mathrm{~m}$ wide and $25 \mathrm{~m}$ long. Moving from the paddle an horizontal bottom characterized the initial $6.5 \mathrm{~m}$, followed by a 1:98 slope that continues until just before the model.

The wave generation paddle is a hydraulic driven piston mode generator. The software AwaSys (Aalborg University, 2010), developed at the same laboratory, is used to generate waves with simultaneously active absorption of reflected waves. Waves are generated based on the JONSWAP spectrum, which is a three parameter spectrum defined by $\mathrm{H}_{\mathrm{m} 0}, \mathrm{f}_{\mathrm{p}}\left(=1 / \mathrm{T}_{\mathrm{p}}\right)$, and the so-called peak enhancement factor $\gamma(\gamma=3.3$ in all tests).

Resistance type wave gauges are used to measure the water surface elevation. In order to separate into incident and reflected waves three wave gauges are installed near the toe of the breakwater. The incident and reflected spectra are determined using the approach of Mansard \& Funke (1980) and the positioning of the wave gauges is based on suggestions by Klopman \& van der Meer (1999).

The OBREC sloping front plate was positioned with a slope of $\theta=34^{\circ}$ and were tested for different freeboards. Tested geometry and wave characteristics are reported in Table 2.

\begin{tabular}{|c|c|c|c|c|c|c|c|c|c|}
\hline Test & $\begin{array}{c}\mathrm{h} \\
{[\mathrm{m}]}\end{array}$ & $\begin{array}{l}\mathrm{H}_{\mathrm{m} 0} \\
{[\mathrm{~m}]}\end{array}$ & $\begin{array}{c}T_{m-1.0} \\
{[s]}\end{array}$ & $\begin{array}{l}\mathrm{R}_{\mathrm{C}} \\
{[\mathrm{m}]}\end{array}$ & $\begin{array}{c}B \\
{[\mathrm{~m}]}\end{array}$ & $\begin{array}{c}\mathrm{H}_{\mathrm{m} 0} / \mathrm{L}_{\mathrm{m}-1.0} \\
{[-]}\end{array}$ & $\begin{array}{c}\mathrm{H}_{\mathrm{mo}} / \mathrm{h} \\
{[-]}\end{array}$ & $\begin{array}{c}\mathrm{R}_{\mathrm{C}} / \mathrm{H}_{\mathrm{m} 0} \\
{[-]}\end{array}$ & $\begin{array}{c}B / L_{m-1.0} \\
{[-]}\end{array}$ \\
\hline $\begin{array}{l}\text { Extreme } \\
\text { (min-max) }\end{array}$ & $\begin{array}{l}0.30 \\
0.34\end{array}$ & $\begin{array}{l}0.141 \\
0.177\end{array}$ & $\begin{array}{l}1.68 \\
2.26\end{array}$ & $\begin{array}{l}0.075 \\
0.125\end{array}$ & 0.488 & $\begin{array}{l}0.04 \\
0.06\end{array}$ & $\begin{array}{l}0.47 \\
0.52\end{array}$ & $\begin{array}{l}0.21 \\
0.85\end{array}$ & $\begin{array}{l}0.12 \\
0.17\end{array}$ \\
\hline $\begin{array}{l}\text { Production } \\
\text { (min max) }\end{array}$ & 0.270 & $\begin{array}{l}0.037 \\
0.138\end{array}$ & $\begin{array}{l}1.05 \\
2.14\end{array}$ & $\begin{array}{l}0.105 \\
0.155\end{array}$ & 0.488 & $\begin{array}{l}0.03 \\
0.06\end{array}$ & $\begin{array}{l}0.14 \\
0.51\end{array}$ & $\begin{array}{l}0.99 \\
2.82\end{array}$ & $\begin{array}{l}0.15 \\
0.34\end{array}$ \\
\hline
\end{tabular}

Extreme conditions were run with different design wave height and SWL with the aim of taking in to account the influence of climate changes leading to rising sea water level and increasing storminess on the loadings and overtopping. Wave average conditions were run to evaluate as first estimate the potential overtopping available for wave energy production.

Overtopping discharge at the rear side of the crown wall for both the conventional structure and OBREC front reservoir have been measured. 
25 pressures transducers sampling at $1500 \mathrm{~Hz}$ where installed on the traditional crown wall measuring horizontal and vertical uplift pressures.

Wave pressures on OBREC were measured using 6 pressures transducers on the frontal sloping plate, 5 pressures transducers on the reservoir outside bottom (uplift pressure) and 16 pressures transducers on the inside reservoir vertical wall/crown wall.

The preliminary analyses is concerning the overtopping performances of OBREC in which the measured overtopping in the rear side of the crow wall and in the rear side of OBREC are compared.

Measured overtopping in the front reservoir is compared with Van der Meer (1998) and CLASH Neural Network (Van Gent et al., 2007). Measured pressure distribution on traditional crown wall (Nørgaard et al., 2012) is compared with the one measured with the presence of a front reservoir.

\section{Overtopping}

The non-dimensional average overtopping discharge $\left(\mathrm{q}^{*}\right)$ and the maximum overtopping single volume $\left(\mathrm{V}^{*}\right)$ are defined as:

$$
\begin{gathered}
q^{*}=\frac{q}{\sqrt{g \cdot H_{m 0}{ }^{3}}} \\
V_{\text {max }}^{*}=\frac{V_{\text {max }}}{H_{s}{ }^{2}}
\end{gathered}
$$

The comparison between the overtopping on the rear side of the traditional rubble mound breakwater with a crown wall $\left(\mathrm{q}^{*}\right.$ orig. $)$ and the innovative OBREC $\left(\mathrm{q}^{*}\right.$ front res. $)$ under extreme conditions do not show any significant variation (Fig. 10). The effect of the front reservoir is almost equal to the dissipation effect to the presence of a rubble mound.

\section{Average overtopping}

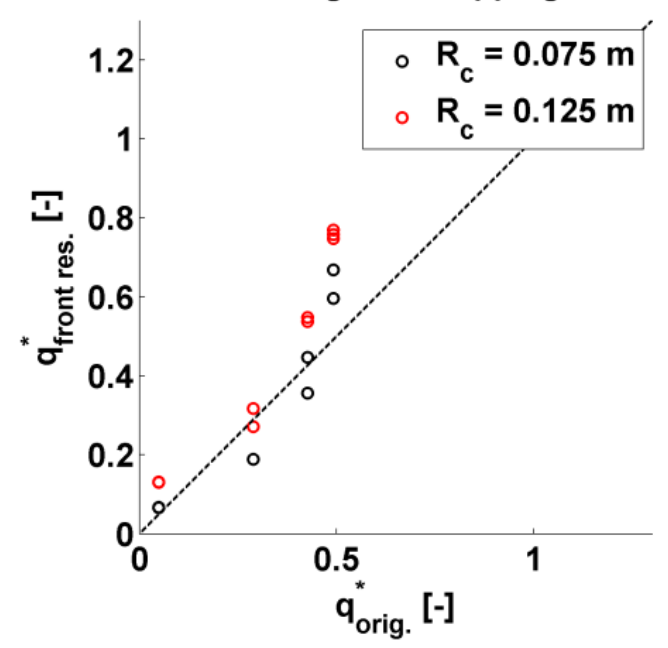

Max single vol.

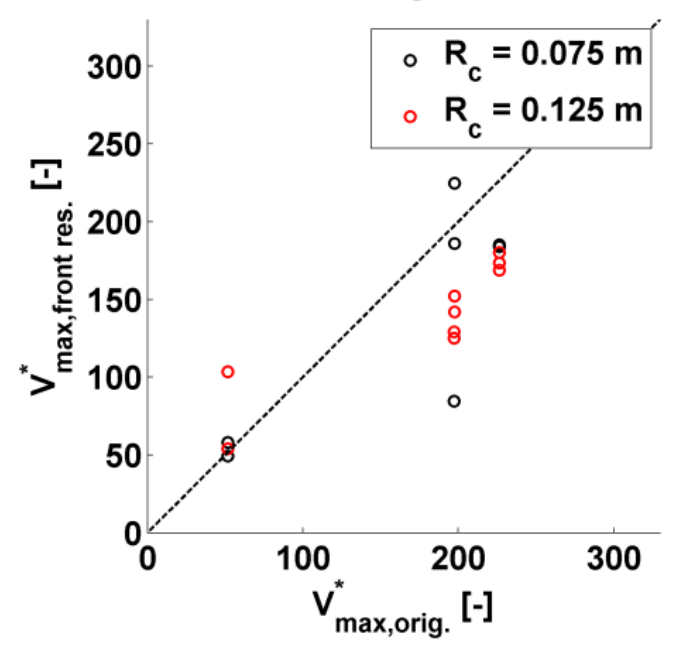

Figure 10. Average wave overtopping and single wave overtopping.

The method of energy capturing of the structure is by storing wave overtopping in the reservoir above SWL and thereby producing electricity from low head turbines returning the water to the sea. Clearly the electricity production of the front reservoir structure depends on the wave overtopping into the reservoir and the potential of the turbines. The potential wave overtopping in the reservoir, which can be easily transformed into the potential electricity production later, is measured under the average wave condition reported in Table 2.

The measured wave overtopping volume in the front reservoir is compared to the calculated wave overtopping discharge using the CLASH Neural Network and using the overtopping formulae by Van 
der Meer (1998). A relatively good estimate on the wave overtopping in the front reservoir is obtained from the overtopping Van der Meer formula using a combined roughness coefficient of $\gamma_{\mathrm{f}} \approx 0.7$ (Fig. 11 and Fig. 12).

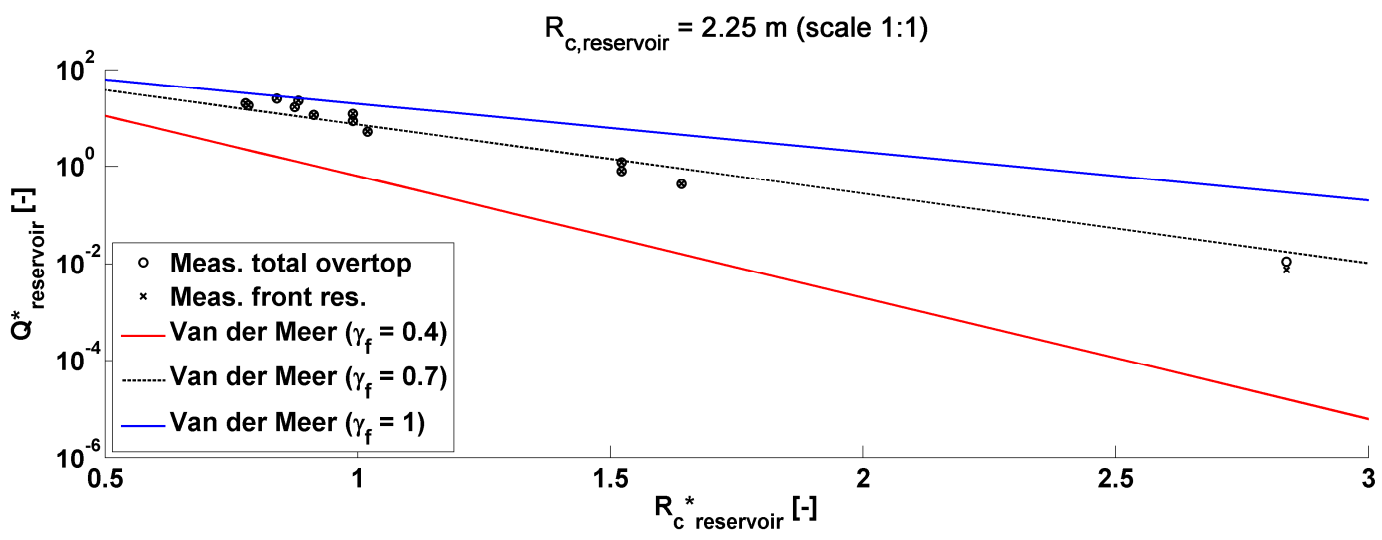

Figure 11. Measured and calculated overtopping discharge in front reservoir (low freeboard).

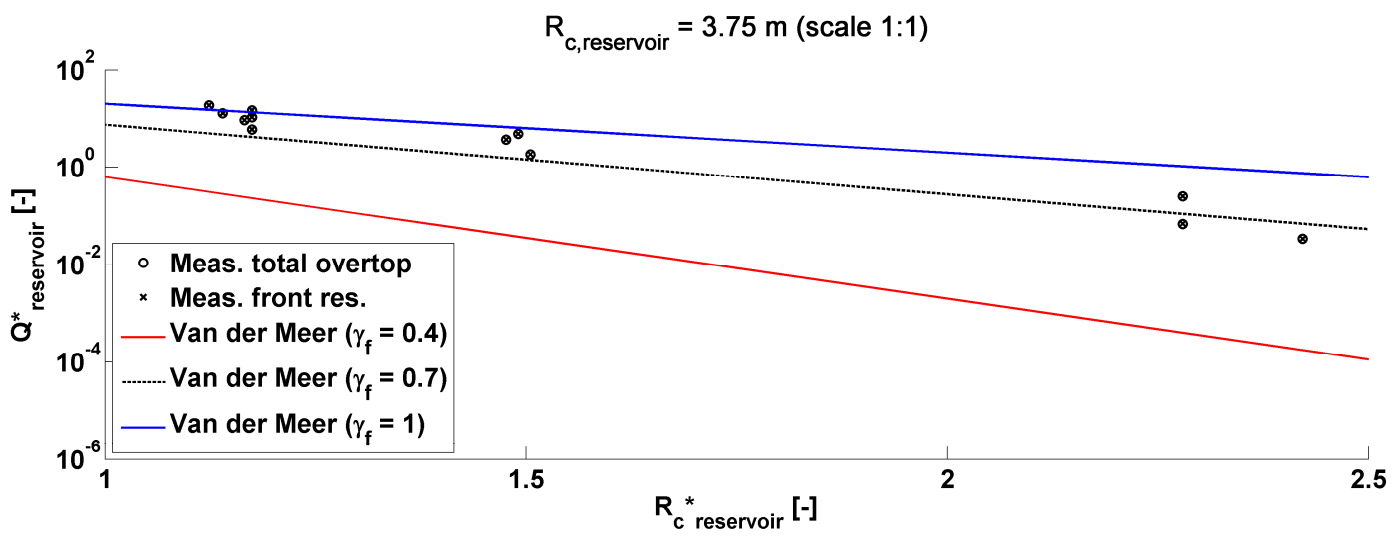

Figure 12. Measured and calculated overtopping discharge in front reservoir (high freeboard).

\section{Pressure distribution}

Wave pressure distribution on a traditional crown wall superstructure is compared to the one acting on OBREC. Wave overall loadings and stability of the innovative structure are not presented here.

The wave conditions illustrated are $\mathrm{H}_{\mathrm{m} 0} / \mathrm{L}_{\mathrm{m}-1.0}=0.06, \mathrm{H}_{\mathrm{m} 0} / \mathrm{h}=0.5, \mathrm{R}_{\mathrm{c}} / \mathrm{H}_{\mathrm{m} 0}=0.5, \mathrm{~B} / \mathrm{L}_{\mathrm{m}-1.0}=0.16$. The pressure distribution on the original crown wall structure are illustrated for the time instance of maximum horizontal force $\left(\mathrm{F}_{\mathrm{H}, \text { max }}\right)$ and maximum vertical force $\left(\mathrm{F}_{\mathrm{V}, \text { max }}\right)$ in Figure 13 and Figure 14 respectively. For comparison the pressure distribution on vertical wall in the front reservoir structure for the time instance of maximum horizontal force, $\mathrm{F}_{\mathrm{H}, \text { crown wall }+ \text { reservoir,max }}$, maximum vertical force $\mathrm{F}_{\mathrm{V} \text {,crown wall }+ \text { reservoir,max }}$, and maximum horizontal force on the front slope, $\mathrm{F}_{\mathrm{H} \text {,front slope }}$, are reported in Figure 15, Figure 16 and Figure 17.

The presence of the front reservoir increase the pressure/loading on the vertical wall/crow wall. The front reservoir on the other hand improve the OBREC overall stability. 


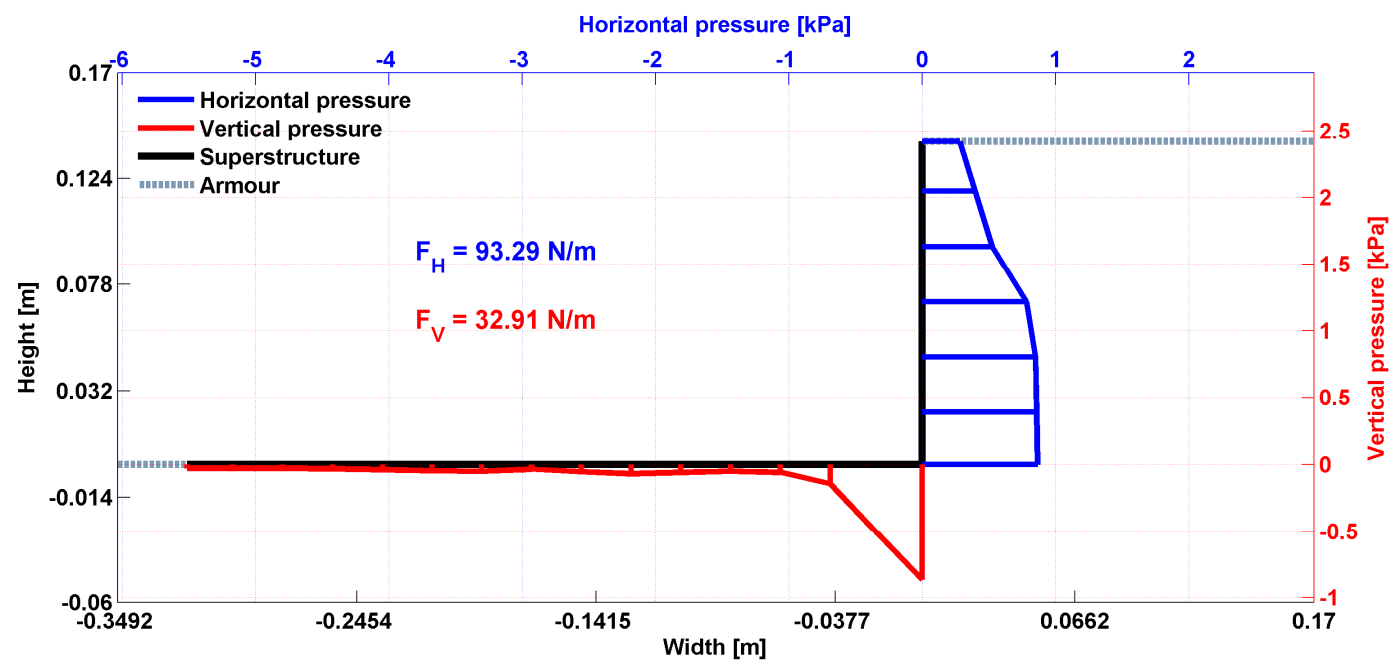

Figure 13. Pressure distribution on original crown wall structure for $F_{\mathrm{H}, \max }$.

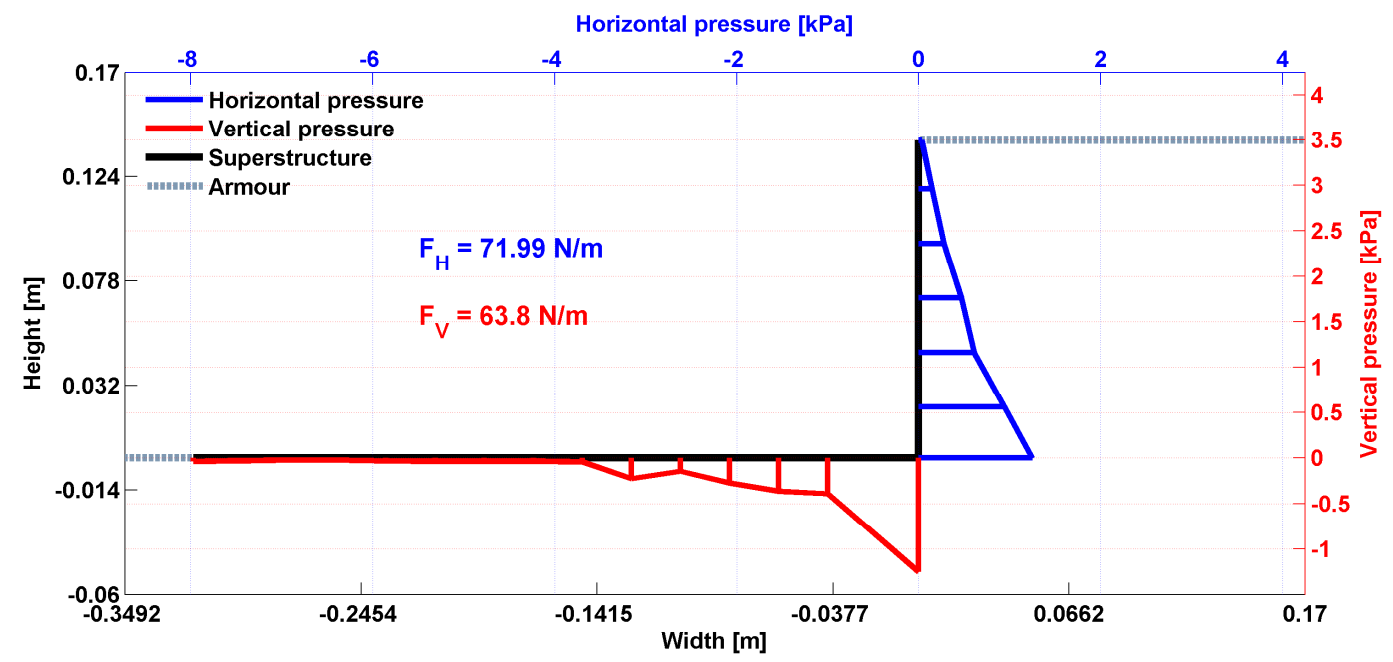

Figure 14 Pressure distribution on original crown wall structure for $F_{V \text {,max. }}$.

Pressure distribution at time for max $\mathrm{F}_{\mathrm{H} \text {,crown wall }+ \text { reservoir }}$ ( time $=\mathbf{3 8 8 . 7 7 ~ \mathrm { s } )}$

Horizontal pressure $[\mathrm{kPa}]$

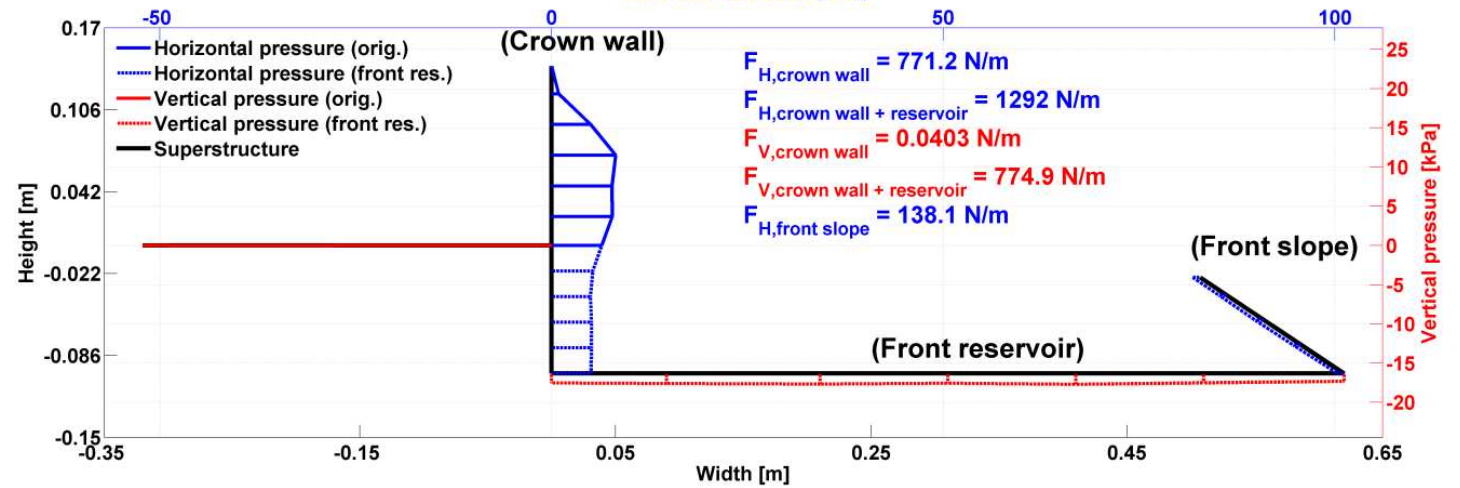

Figure 15. Pressure distribution on OBREC for $F_{\mathrm{H}, \text { crown wall + reservoir,max- }}$ 


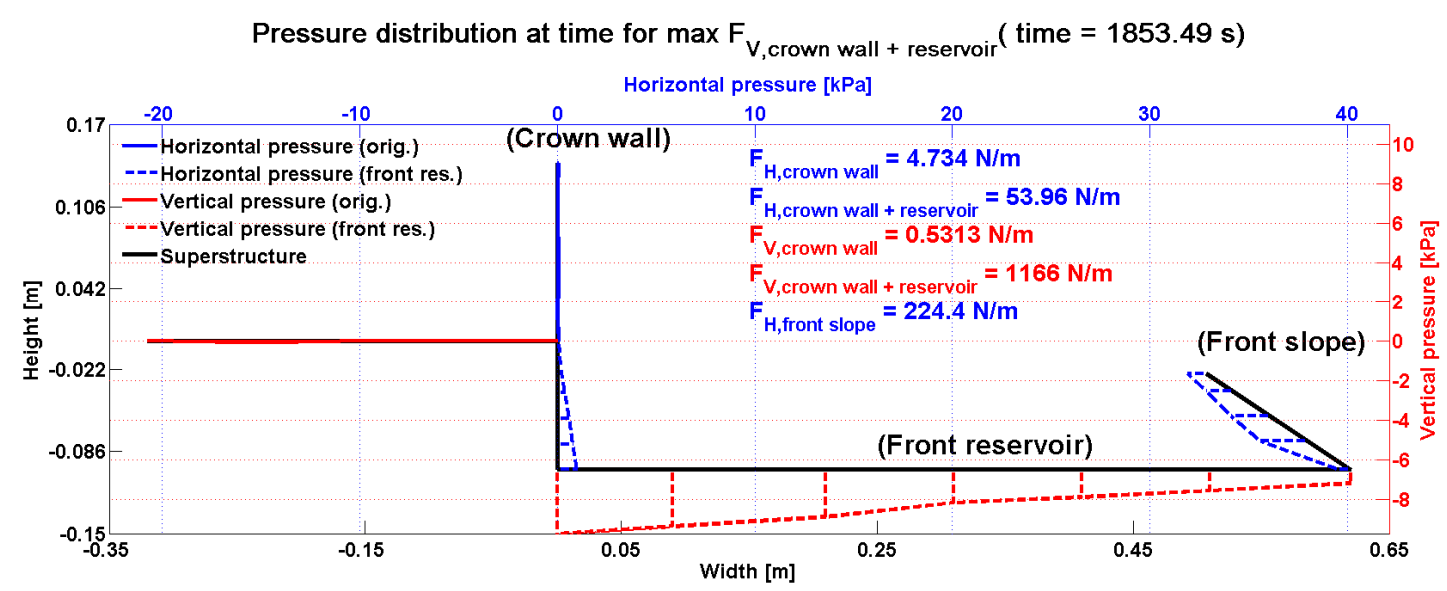

Figure 16. Pressure distribution on OBREC for $F_{\mathrm{V}, \text { crown wall + reservoir,max. }}$

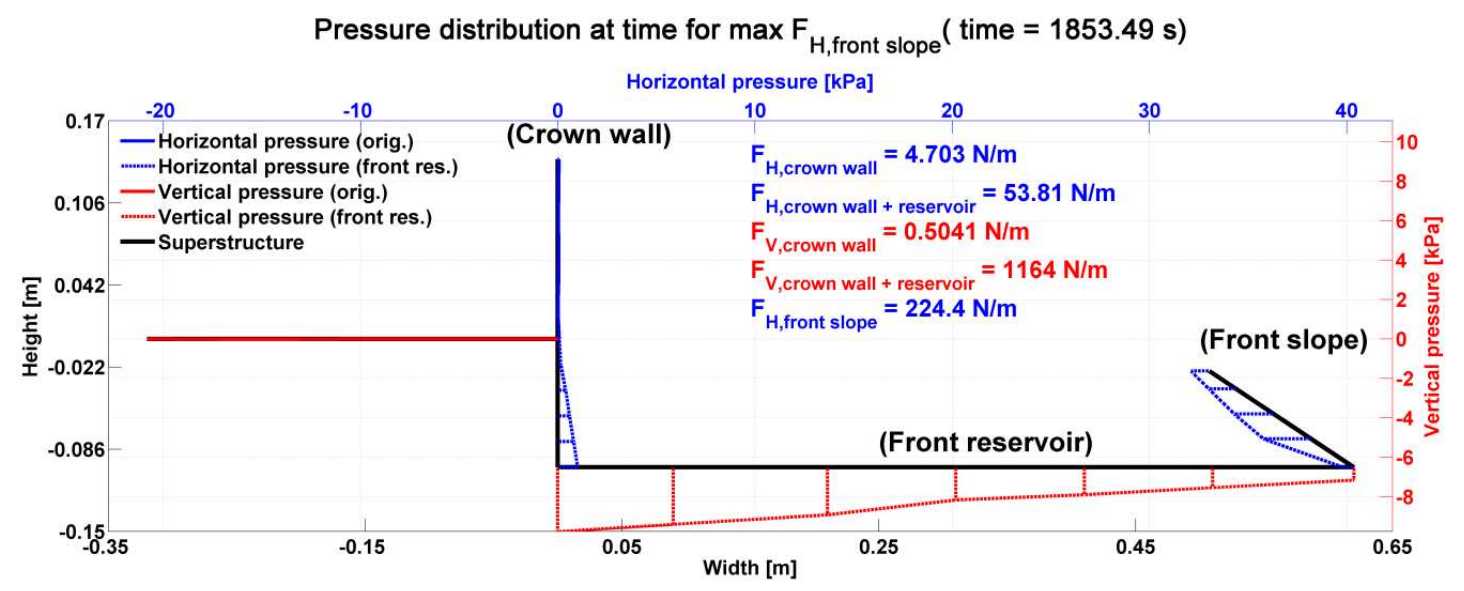

Figure 17. Pressure distribution on OBREC for $F_{\mathrm{H} \text {,ront slope. }}$

\section{CONCLUSIONS}

A preliminary analysis on two innovative coastal structure have been performed and preliminary results are encouraging. Tidal effects are not taken in to account in this contribution and it will be part of the future research improvements.

Sea Wall wave OverTopping Device (SW-OTD) tests have shown how the presence of a front reservoir can strongly reduce the loading on the vertical wall and the overtopping on the rear side. A feasibility study is in progress at Southampton University.

Overtopping BReakwater for Energy Conversion (OBREC) measured loadings and overtopping indicates that the innovative structure needs a cost benefit analysis in a real feasibility study in comparison with a traditional rubble mound breakwater to show how the innovative structure can have a reasonable payback.

\section{ACKNOWLEDGMENTS}

The first Author gratefully acknowledges the Department of Civil Engineering of Aalborg University and of Second University of Naples for encouraging mobility of researchers.

The support of the European Commission through FP7.2009-1, Contract 244104 - THESEUS ("Innovative technologies for safer European coasts in a changing climate"), is gratefully acknowledged. 


\section{REFERENCES}

Burcharth, H. F. and Lykke Andersen, T. 2006. Overtopping of rubble mound breakwaters with front reservoir, Proceedings of 30th International Conference on Coastal Engineering, ASCE, 46054615.

EOEA (European Ocean Energy Association). 2012. European Ocean Energy Roadmap 2010-2050, http://www.eu-oea.com/wp-content/uploads/2012/02/EUOEA-Roadmap.pdf

Geeraerts, J., De Rouck, J., Beels, C., Gysens, S. \& DeWolf, P. 2006. Reduction of Wave Overtopping at Seadikes: Stilling Wave Basin, Proceedings of 30th International Conference on Coastal Engineering, ASCE, 4680-4691.

Margheritini, L., Vicinanza, D. and Frigaard, P. 2009. SSG wave energy converter: Design, reliability and hydraulic performance of an innovative overtopping device, Journal of Renewable Energy, 34, 1371-1380.

Mori, M., Yamamoto, Y. \& Kimura, K. 2008. Wave force and stability of upright section of high mound composite seawall, Proceedings of 31st International Conference on Coastal Engineering, Hamburg, ASCE, 3164-3172.

Nørgaard, J. H., Andersen, L. V., Andersen, T. L., Burcharth, H. F. 2012. Stability of monolithic rubble mound breakwater crown walls subjected to impulsive loading, Proceedings of 33th International Conference on Coastal Engineering, ASCE, (in this proceedings).

Stagonas, D., Muller, G., Maravelakis, N., Magagna, D. \& Warbrick, D. 2010. Composite seawalls for wave energy conversion: 2D experimental results, $3^{\text {rd }}$ International Conference on Ocean Energy.

Van der Meer, J.W. 1998. Wave run-up and overtopping. Chapter 8 in: Seawalls, dikes and revetments. Edited by K.W. Pilarczyk. Balkema, Rotterdam.

Van Gent M. R. A., Van den Boogaard H. F. P., Pozueta B., Medina J. R. 2007. Neural network modelling of wave overtopping at coastal structures, Coastal Engineering, 54(8), 586-593.

Vicinanza, D. and Frigaard, P. 2008. Wave pressure acting on a seawave slot-cone generator, Coastal Engineering, 55(6), 553-568.

Vicinanza, D., Ciardulli, F., Buccino, M., Calabrese, M., Koefed, J. P. 2011. Wave loadings acting on an innovative breakwaters for energy production, Journal of Coastal Research, 64, 608 - 612.

Vicinanza, D., Margheritini, L., Kofoed, J. P. \& Buccino, M. 2012. The SSG Wave Energy Converter: Performance, Status and Recent Developments, Energies, 5(2), 193-226. 